\title{
Metallic Biosorption Using Yeasts in Continuous Systems
}

\author{
Karla Miriam Hernández Mata, ${ }^{1}$ Onofre Monge Amaya, ${ }^{1}$ María Teresa Certucha Barragán, \\ Francisco Javier Almendariz Tapia, ${ }^{1}$ and Evelia Acedo Félix ${ }^{2}$ \\ ${ }^{1}$ Department of Chemical Engineering and Metallurgy, University of Sonora, Rosales y Boulevard Luis Encinas, Col. Centro., \\ 83000 Hermosillo, Son, Mexico \\ ${ }^{2}$ Research Center Nutrition and Development, A.C., Carretera a La Victoria km 0.6, 83304 Hermosillo, Son, Mexico
}

Correspondence should be addressed to Onofre Monge Amaya; onofrem@iq.uson.mx

Received 4 January 2013; Accepted 1 July 2013

Academic Editor: Nabil Abdel-Jabbar

Copyright (C) 2013 Karla Miriam Hernández Mata et al. This is an open access article distributed under the Creative Commons Attribution License, which permits unrestricted use, distribution, and reproduction in any medium, provided the original work is properly cited.

\begin{abstract}
Mining effluents were found to be the main source of pollution by heavy metals of the surface water in the San Pedro River in Sonora, Mexico. The overall objective of this study was to determine the biosorption of $\mathrm{Zn}, \mathrm{Cu}, \mathrm{Mn}$, and Fe with yeasts isolated from San Pedro River in a continuous system. The tests conducted in two reactors packed with zeolite connected in series. The first reactor was inoculated mixing two yeasts species, and the effluent of the first reactor was fed to second reactor. Subsequently, the first reactor was fed with contaminated water of San Pedro River and effluent from this was the second reactor influent. After 40 days of the experiment a reduction of $81.5 \%$ zinc, $76.5 \%$ copper, manganese $95.5 \%$, and $99.8 \%$ of iron was obtained. These results show that the selected yeasts are capable of biosorbing zinc, copper, manganese, and iron under these conditions.
\end{abstract}

\section{Introduction}

Heavy metal pollution is one of the most relevant environmental problems nowadays. Several industries such as mining, energy and fuel production, pesticide industry, metallurgy, electrolysis, photography, aerospace, among others, produce and discharge waste into the environment waste containing various heavy metals [1]. In our country, we have found a history of heavy metal contamination in surfaces water of the San Pedro River in Sonora [2], where the main source of pollution is mining effluents. For decades, studies and methods have been developed remedy the pollution of toxic metals by mining and metallurgical industry [3].

Existing techniques were developed for the removal of heavy metals from wastewater including chemicals: precipitation, neutralization, ion exchange, membrane separation, electrodialysis, and adsorption by activated carbon; however, all these methods have the disadvantage of secondary contamination [4]. Additionally, it is especially difficult to treat large volumes of domestic and industrial water containing low concentrations of heavy metals $(1-100 \mathrm{mg} / \mathrm{L})$.

Furthermore, a more environmental treatment is biosorption, which is based on bioremediation that is defined as a natural process whereby various microorganisms are capable of removing organic and inorganic contaminants in a given environment, and this allows mainly the reuse of the contaminated area and the recovery of the ecological balance [5]. Microorganisms, as heavy metal bioadsorbents, offer a new alternative for removal or detoxification of toxic or valuable metals in industrial wastewater. There are a variety of microorganisms with the ability to capture significant amounts within them from dilute solutions [6].

The biosorption process with living biomass is a very interesting alternative for the restoration of sites contaminated with heavy metals, as previous studies showed to be effective when you have low concentrations of metals. The study of the interactions of microorganisms and metals may be useful in understanding the relationships between toxic metals with higher organisms such as mammals and plants [7].

There have been studies with polymers as support material for the immobilization of microorganisms; however, the work and the stability of the gels are problem due to solubility in water. This limits its use in industrialization and largescale applications [8]. There are other materials that are used 


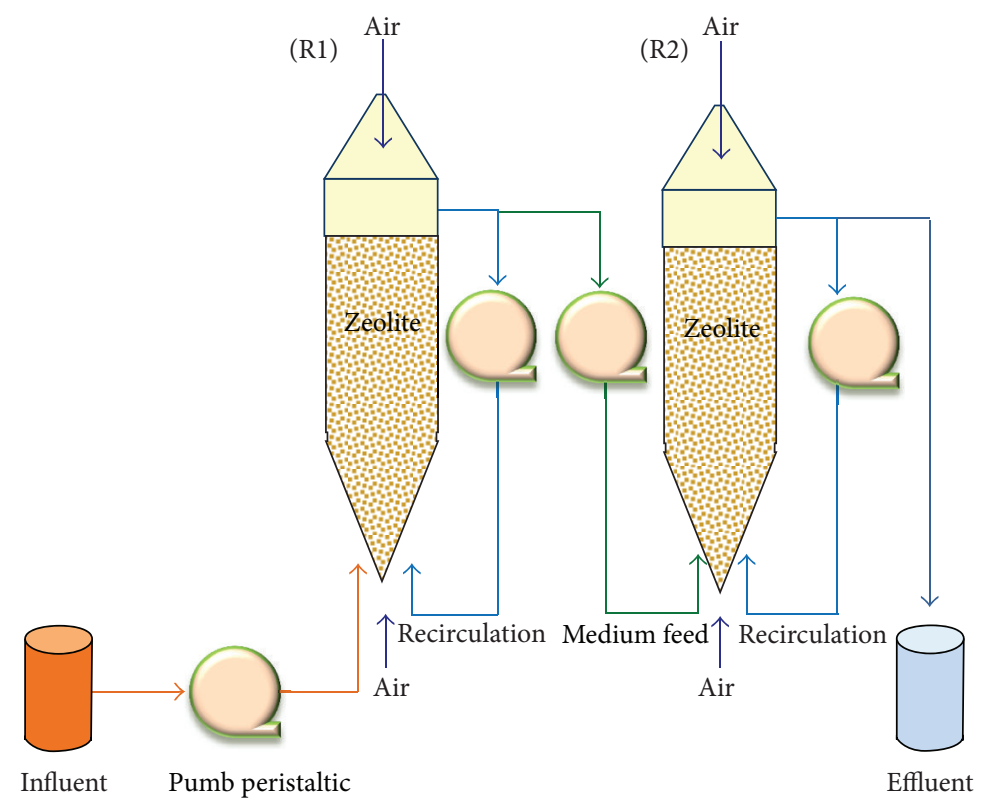

FIGURE 1: Schematic diagram of the upstream flow of the aerobic reactors packed with zeolite.

as support for biomass, such as natural zeolites that have shown major industrial applications due to their great affinity for water and their cavities that only allow the passage of molecules of a certain size. Natural zeolites have been used as additives in animal feed, as soil improvers in agriculture due to increased nitrogen retention and soil moisture, and as catalysts in industrial processes of refining, petrochemicals, and fine chemicals [2].

The aim of this work was to determine the biosorption of zinc $(\mathrm{Zn})$, copper $(\mathrm{Cu})$, manganese $(\mathrm{Mn})$, and iron $(\mathrm{Fe})$ with immobilized yeast Issatchenkia orientalis (Io) and Candida tropicalis $(\mathrm{Ct})$ on zeolite, with a continuous two-reactor aerobic upflow system. The system industrial effluents with concentrations above the Official Mexican Norm (NOM-001ECOL-1996), especially copper, zinc, manganese, and iron. This work seeks an alternative for heavy metals biosorption with a consortium of yeasts isolated from the Rio San Pedro.

\section{Methodology}

2.1. Geographic Location of Sampling. The geographical location of the sample site of the Rio San Pedro was as follows: station 1 , latitude $30^{\circ} 59^{\prime} 45^{\prime \prime}$, and longitude $110^{\circ} 17^{\prime} 22^{\prime \prime}$. These waters were those used for testing biosorption of heavy metals in the continuous system. The $\mathrm{pH}$ of the water collected was 3.3 ; this is probably because the place is closed to mine effluents.

2.2. Biomass Material. The yeast strains used were isolated from the water of the Rio San Pedro, Sonora in a previous study and were identified as Issatchenkia orientalis (Io) and Candida tropicalis (Ct) [9].

2.3. Continuous Biosorption Tests. Biosorption of heavy metals testing was performed on system continued in two aerobic reactors upflow packed with zeolite (clinoptilolite) connected in series as shown in Figure 1. The reactors were glass of $49.3 \mathrm{~cm}$ long by $6.9 \mathrm{~cm}$ internal diameter, with a side outlet at the top of the reactor for taking of samples and a volume of $1.5 \mathrm{~L}$. The reactors were packed with $1000 \mathrm{~g}$ of zeolite with a size of 3-4 mm. The air feed and the mineral medium were conducted by the lower part of the reactor, using a peristaltic pump at $2.5 \mathrm{~mL} / \mathrm{min}$. The mineral medium is composed of (g/L) of 5 glucose, 3 ammonium phosphate, 3 potassium phosphate, 0.2 magnesium sulfate, and 5 sodium chloride to an acid $\mathrm{pH}$ of 3-4 [2].

The mixture of yeasts was inoculated into the first reactor (R1), and the biomass produced was subsequently fed to the second reactor (R2). The biomass was recirculated in each reactor for 5 days until a concentration of $1 \mathrm{~g} / \mathrm{L}$ of biomass was obtained, which was suitable to start feeding the contaminated waters and start testing the biosorption capacity [2].

The first reactor (R1) was fed with contaminated water whose effluent was the influent for the second reactor (R2). The conditions of operation of the reactors were as follows: air flow $3.5 \mathrm{~mL} / \mathrm{min}$, feed rate $0.7 \mathrm{~mL} / \mathrm{min}$, hydraulic retention time (HRT) of 1 day at $26^{\circ} \mathrm{C}$, and $\mathrm{pH}$ between 3 and 4 .

\section{Results}

In the first reactor a rapid population development with the consortium of the two strains of yeast was observed. This occurs due to the fact that the Candida tropicalis strain shows maximum growth of 180 minutes, while the growth time for Issatchenkia orientalis is 260 minutes [9].

Table 1 shows a comparison of the removal efficiencies of heavy metals in each reactor, where high removals of $\mathrm{Mn}$, $\mathrm{Fe}, \mathrm{Zn}$, and $\mathrm{Ni}$ can be observed. After the fifth day of the experiment the removal percentage decreases slowly for zinc, 

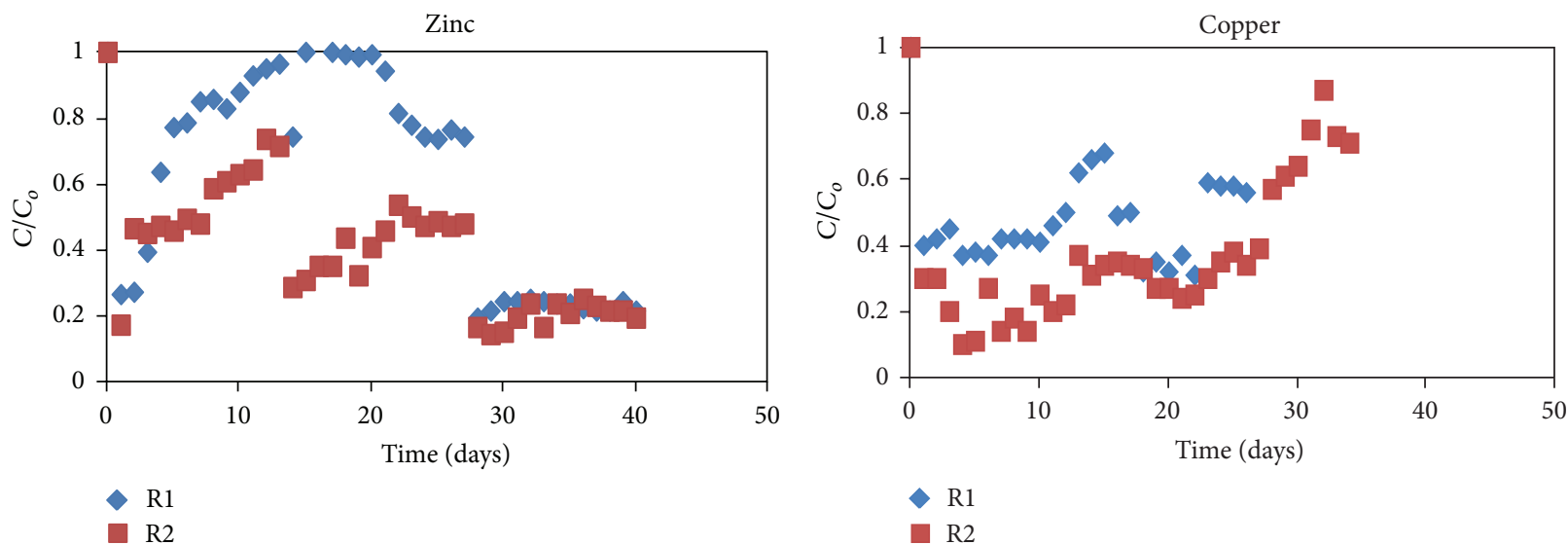

(a)

(b)
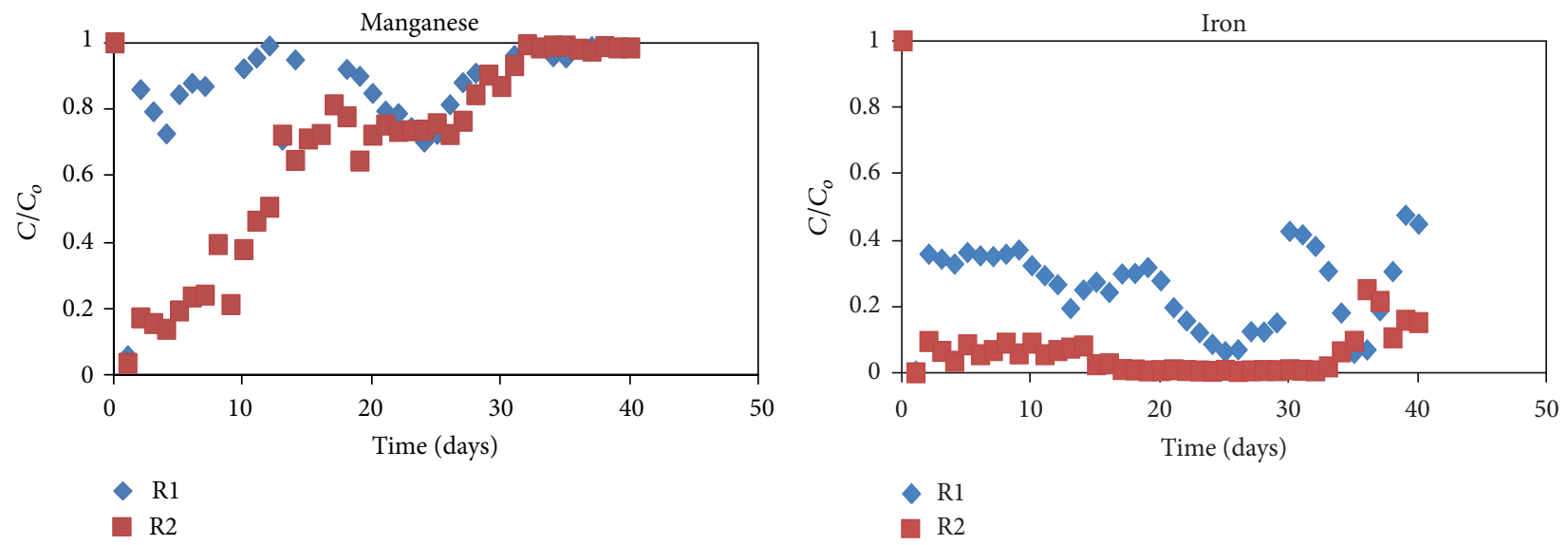

(c)

(d)

Figure 2: Biosorption kinetics of $\mathrm{Zn}, \mathrm{Cu}, \mathrm{Mn}$, and $\mathrm{Fe}$ in a continuous system, using Issatchenkia orientalis and Candida tropicalis yeasts immobilized in clinoptilolite zeolite.

TABLE 1: Percentage removal of heavy metals.

\begin{tabular}{lcc}
\hline Metal & \% Removal R1 & \% Removal R2 \\
\hline Zinc & 80 & 83 \\
Copper & 63 & 90 \\
Manganese & 94.3 & 97 \\
Iron & 99.5 & 100 \\
\hline
\end{tabular}

copper, and manganese, and iron moreover is enhanced until the end of the process; this can be seen in Figure 2.

Figure 2 shows the removal of heavy metals; the efficiency of the immobilization of yeasts to biosorb zinc is observed, obtaining a percentage of $80 \%$ and $83 \%$ in $\mathrm{R} 1$ and $\mathrm{R} 2$, and specifies that the concentrations found in San Pedro River do not exceed the $20 \mathrm{mg} / \mathrm{L}$ according to Mexican Norm. This demonstrates efficacy in the efficiency removal of the system. Zinc removal of $94 \% \pm 0.3 \%$, using immobilized $S$. cerevisiae yeast, has been reported in the literature, with an initial concentration of $750 \mathrm{mg} / \mathrm{L}$, of a synthetic solution, at $\mathrm{pH} 6$ and a flow rate of $2.5 \mathrm{~mL} / \mathrm{min}$ [10].

The same figure shows $\mathrm{Cu}$ biosorption capacity in continuous systems of both columns. R1 shows that in the first five days a 63\% metal removal was obtained, and 90\% in R2. It is noteworthy that biomass continues biosorbing at day 25 , still in significant quantities of metal below the standard, which establishes the maximum permissible limits for copper are $6 \mathrm{mg} / \mathrm{L}$. On the other hand, studies with Saccharomyces cerevisiae, immobilized in sepiolite for $\mathrm{Cu}$ adsorption, have shown favorable results of $98.3 \pm 0.4 \%$. This takes place at an initial concentration of $500 \mathrm{mg} / \mathrm{L}$ of synthetic solution with $\mathrm{pH} 8$ and a flow rate of $2.5 \mathrm{~mL} / \mathrm{min}$ [10]. Other authors report the use of Celtek clay as biosorbent of heavy metals; the adsorption of the metals increased with increasing dosage of the clay [11].

Manganese biosorption in the figure reveals $94.3 \%$ in $\mathrm{R} 1$ and 97\% metal removal in R2. Studies report that with $14 \mathrm{~g} / \mathrm{L}$ of biomass of Saccharomyces cerevisiae ICCF 349 and Saccharomyces bayanus ICCF 348, resist concentrations of $1250 \mathrm{mg} / \mathrm{L}$ manganese sulfate $\left(\mathrm{MnSO}_{4}\right)$, which can retain $33.9 \mathrm{mg} / \mathrm{L}$ manganese [12]. Exposure to high concentrations of manganese leads to a toxic effect, so that the use of these yeasts can be an alternative for treating contaminated wastewater with manganese.

Iron biosorption shown in the figure proves the efficiency of yeasts as biosorbent, since it was determined that the metal 
TABLE 2: Removal of heavy metals in reactors with yeast immobilized into zeolites.

\begin{tabular}{lcccc}
\hline Metal & $\begin{array}{c}C_{0} \\
(\mathrm{mg} / \mathrm{L})\end{array}$ & $\begin{array}{c}C_{f(\mathrm{R} 1)} \\
(\mathrm{mg} / \mathrm{L})\end{array}$ & $\begin{array}{c}C_{f(\mathrm{R} 2)} \\
(\mathrm{mg} / \mathrm{L})\end{array}$ & $\begin{array}{c}\text { NOM-001-ECOL-1996 } \\
(\mathrm{mg} / \mathrm{L})\end{array}$ \\
\hline Zinc & 14 & 3 & 2 & 20 \\
Copper & 10 & 3.7 & 1 & 6 \\
Manganese & 52.5 & 3 & 1.8 & 4 \\
Iron & 403 & 2 & 0 & 5 \\
\hline
\end{tabular}

removal rate in the river water for $\mathrm{R} 1$ was $99.5 \%$ and for $\mathrm{R} 2$ as $100 \%$ removal was obtained.

The Mexican Norm establishes that the maximum permissible limits for iron are $5 \mathrm{mg} / \mathrm{L}$; in this study results that comply with the standard were obtained. Bağ et al. reported that the yeast $S$. cerevisiae immobilized on sepiolite for the adsorption of iron, obtaining a removal of $95 \pm 1 \% \mathrm{Fe}$ [13]. In this study, similar results were obtained with yeasts Candida tropicalis and Issatchenkia orientalis, which demonstrate that the presence of $\mathrm{Zn}, \mathrm{Cu}$, and $\mathrm{Mn}$ promote the adsorption of $\mathrm{Fe}$ in this biomass.

Table 2 shows initial and final concentrations of heavy metals ( $\mathrm{Zn}, \mathrm{Cu}, \mathrm{Mn}$, and $\mathrm{Fe}$ ) of water to be introduced into the reactor, showing decrease in concentration from the first day of experimentation. It also presents the values in the Mexican Official Norm, which establishes the maximum permissible in $\mathrm{mg} / \mathrm{L}$ for zinc, copper, iron, and manganese.

\section{Conclusions}

In this work, biosorption studies using yeast (Candida tropicalis and Issatchenkia orientalis) demonstrate the biosorption capacity of heavy metals such as zinc, copper, manganese and iron. These were undertaken in acidic conditions and continuous systems for 40 days of experimentation. It is worthwhile to mention that excellent results were obtained as a result of the concentrations of the studied metals, which are below the values established by the Mexican Official Standard. It is concluded that the application of this process of bioremediation can be an alternative for the treatment of wastewater contaminated with these metals.

\section{Acknowledgments}

The National Council of Science and Technology (CONACYT) in addition to the Department of Chemical Engineering and Metallurgy of the University of Sonora are thanked for their research support.

\section{References}

[1] I. Acosta, M. G. Moctezuma-Zárate, J. F. Cárdenas, and C. Gutiérrez, "Bioadsorción de cadmio (II) en solución acuosa por biomasas fúngica," Inf. Tec, vol. 18, pp. 9-14, 2007.

[2] O. Monge, J. Valenzuela, E. Acedo, M. Certucha, and F. Almendáriz, "Biosorción de cobre en sistema por lote y continuo con bacterias aerobias inmovilizadas en zeolita natural (clinoptilolita)," Revista Internacional de Contaminación Ambiental, vol. 24, no. 3, 2008.

[3] V. Flores, N. Tapia, and H. Maldonado, "Biorremediación de metales tóxicos en efluentes mineros aplicando biosorción," Revista del Instituto de Investigación de la Facultad de Geología, Minas, Metalurgia Y Ciencias Geográficas, vol. 4, no. 7, 2001.

[4] V. K. Gupta and A. Rastogi, "Biosorption of lead from aqueous solutions by green algae Spirogyra species: kinetics and equilibrium studies," Journal of Hazardous Materials, vol. 152, no. 1, pp. 407-414, 2008.

[5] J. Deuren, Z. Wang, and J. Ledbetter, Remediation Technologies Screening Matrix and Reference Guide, Technology Innovation Office, EPA, 3rd edition, 1997.

[6] S. T. L. Volke, T. J. A. Velasco, P. D. A. De la Rosa, and O. G. Solórzano, Evaluación de Tecnologías de Remediación Para Suelos Contaminados Con Metales, Inedirección de Investigación en Residuos Y Proyectos Regionales, Primer Informe, 2004.

[7] C. Cervantes, "Las bacterias y los metales relaciones peligrosas?” Carisma De La Ciencia, vol. 3, pp. 5-8, 2006.

[8] R. Leyva Ramos, C. N. A. Medellín, C. R. M. Guerrero, M. M. S. Berber, P. A. Aragón, and A. A. Jacobo, "Intercambio iónico de plata (I) en solución acuosa sobre clinoptilolita," Revista Internacional de Contaminación Ambiental, vol. 21, no. 4, pp. 193-200, 2005.

[9] O. Monge, C. Jaramillo, J. Almendariz, and T. Certucha, "Isolation of Microorganisms in Mining Effluent," in Proceedings of the 19th International Conference on Extractive Metallurgy, Recent Developments in Metallurgy, Materials and Environment, 2010.

[10] H. Bağ, M. Lale, and A. R. Türker, "Determination of $\mathrm{Cu}, \mathrm{Zn}$ and Cd in water by FAAS after preconcentration by baker's yeast (Saccharomyces cerevisiae) immobilized on sepiolite," Fresenius' Journal of Analytical Chemistry, vol. 363, no. 3, pp. 224-230, 1999.

[11] A. Sari, M. Tuzen, and M. Soylak, "Adsorption of Pb(II) and $\mathrm{Cr}$ (III) from aqueous solution on Celtek clay," Journal of Hazardous Materials, vol. 144, no. 1-2, pp. 41-46, 2007.

[12] I. D. Barbulescu, N. Rusu, R. Rughinis, O. Popa, A. Stefaniu, and A. Casarica, "Obtaining yeast biomass enriched with copper, zinc and manganese," Romanian Biotechnological Letters, vol. 15, no. 1, pp. 5008-5016, 2010.

[13] H. Bağ, M. Lale, and A. R. Türker, "Determination of iron and nickel by flame atomic absorption spectrophotometry after preconcentration on Saccharomyces cerevisiae immobilized sepiolite," Talanta, vol. 47, no. 3, pp. 689-696, 1998. 

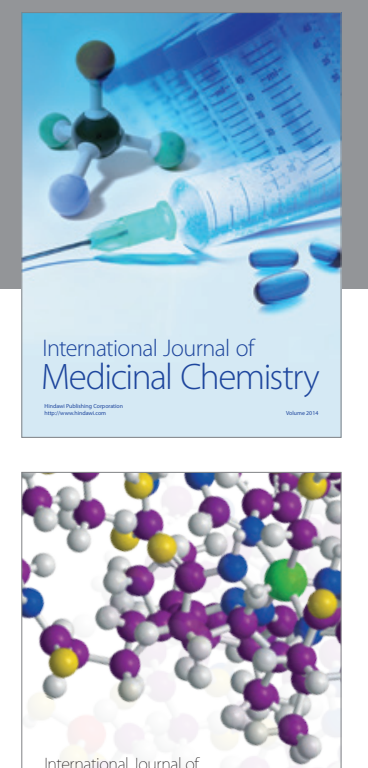

\section{Carbohydrate} Chemistry

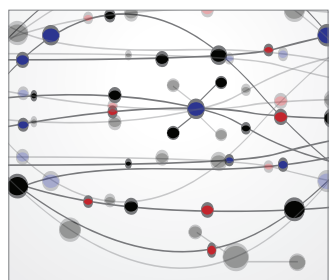

The Scientific World Journal
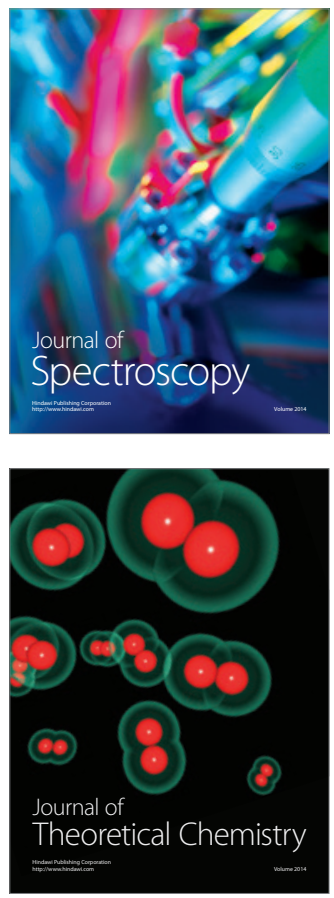
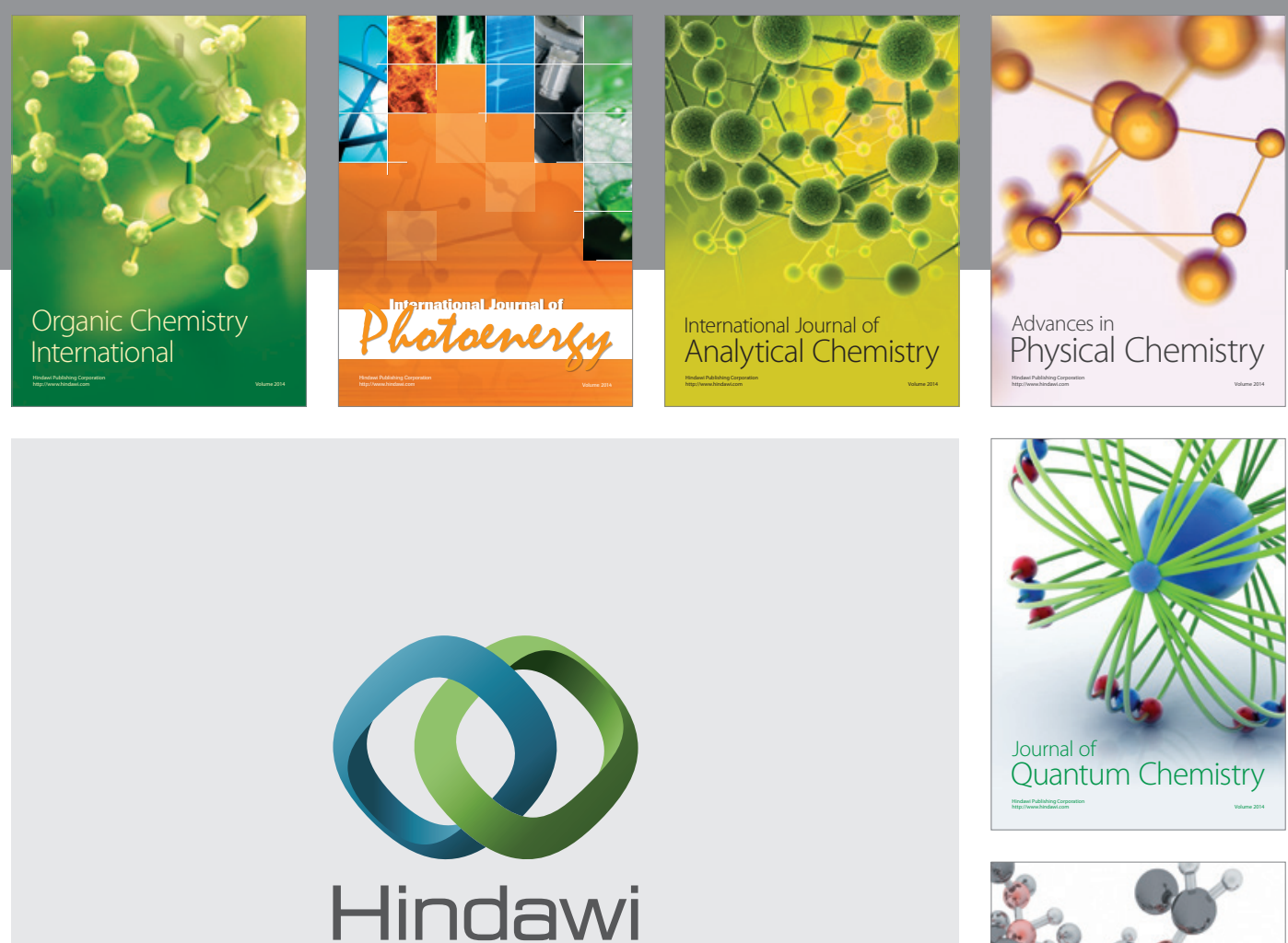

Submit your manuscripts at

http://www.hindawi.com

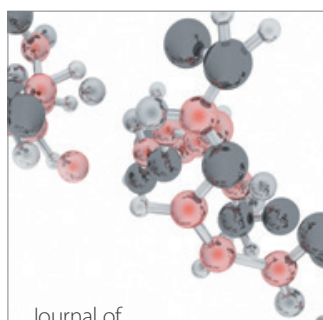

Analytical Methods

in Chemistry

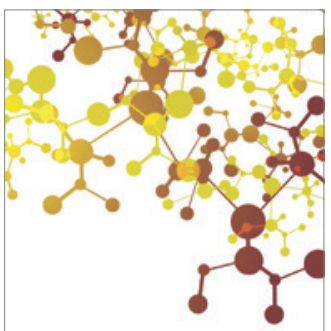

Journal of

Applied Chemistry

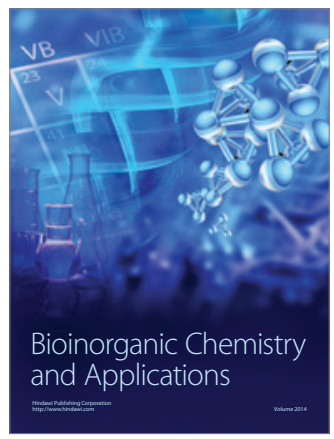

Inorganic Chemistry
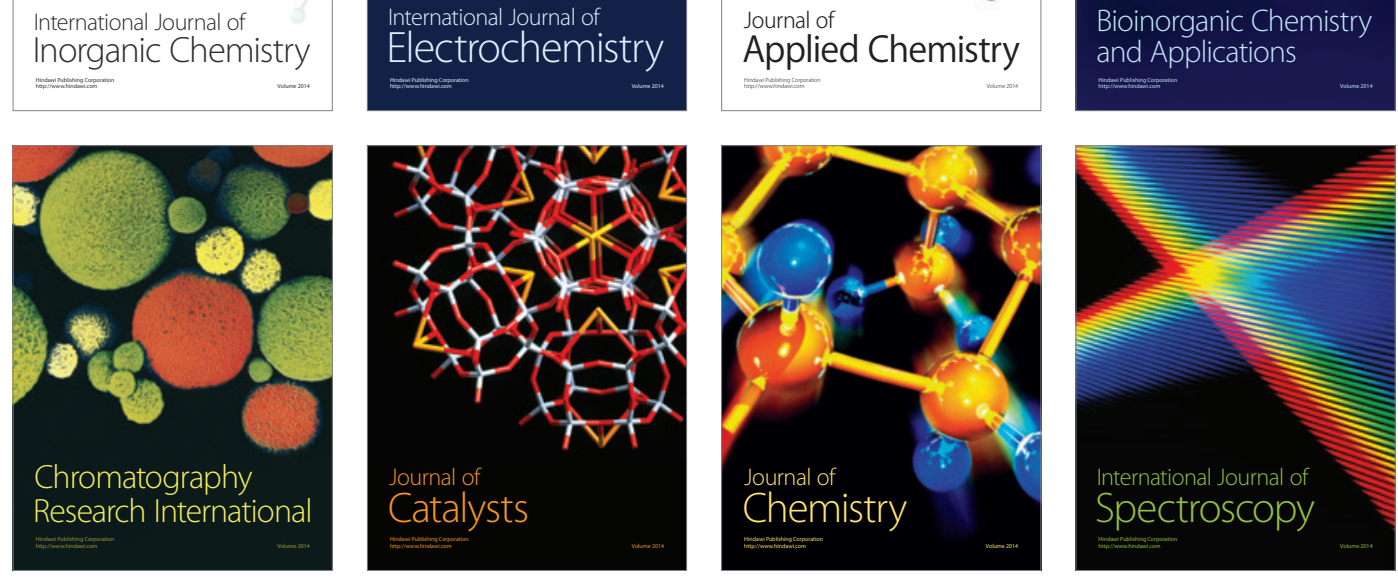